W publikacji znalazły się równie ciekawe artykuły dotyczące wychowania patriotycznego przez sztukę i muzykę. Ks. Wacław Piotr Partyka wskazuje na fakt oddziaływania sztuk plastycznych na człowieka, podkreślając, że dzieło sztuki jest nauczycielem patriotyzmu. Omawia bogactwo polskiej sztuki religijnej, która wpływa na kształtowanie się postawy patriotyzmu (s. 581). Natomiast ks. Andrzej Zwoliński przekonuje czytelnika do społecznej użyteczności muzyki. Przedstawiając rys historyczny wpływu muzyki na kształtowanie się polskiej świadomości narodowości (Fryderyk Chopin) i ukazując wartość hymnów narodowych nie tylko w Polsce, ale i w świecie, podkreśla, że „muzyka w swej istocie jest wielowymiarowa. Polityka to zaledwie jedna z jej form. Ale granicę między muzyką a polityką przekraczano wielokrotnie, sięgając do bogactwa jej przekazu. Słowo wzmocnione muzyką staje się bardziej nośne, politycznie zyskujące na sile, dobrze nadając się do funkcji propagandowych... W każdym wypadku muzyka ujawniała swe nieocenione oddziaływanie społeczne" (s. 604). Podobny wydźwięk ma artykuł Anny Sokołowskiej Znaczenie pieśni patriotycznych w nauczaniu $i$ wychowaniu młodzieży.

Ostatnia część publikacji prezentuje postacie, które poświęciły swoje życie dla Ojczyzny. Pierwszą z nich jest św. Józef Sebastian Pelczar, a następnie: bł. ks. Bronisław Markiewicz, Anna Jenke, Sługa Boży kard. Stefan Wyszyński, ks. Jerzy Popiełuszko, Sługa Boży Jan Paweł II. To wybitni Polacy, którzy są i nadal mogą być wielkimi autorytetami w miłości do Ojczyzny.

Publikacja zawiera niezwykle dużo treści dotyczących wychowania patriotycznego w dobie integracji Polski z Unią Europejską. Mogą być one kopalnią materiałów do ćwiczeń nie tylko na zajęciach w szkołach podstawowych, gimnazjalnych, ponadgimnazjalnych, ale i na uniwersytetach. Znajdą w niej materiały do dalszych badań zarówno przedstawiciele nauki, jak i praktycy: rodzice, katecheci, wychowawcy. Można powiedzieć, że istotę tej publikacji oddają słowa Jana Pawła II wypowiedziane w Częstochowie 18 czerwca 1983 roku: „Czuję się odpowiedzialny za to wielkie, wspólne dziedzictwo, któremu na imię Polska. To imię nas wszystkich określa. To imię nas wszystkich zobowiązuje. To imię nas wszystkich kosztuje".

Czestaw Kustra*

\title{
Marzena Dycht, Rozwój polskiej pedagogiki specjalnej w świetle dokonań jej twórców, Wydawnictwo Uniwersytetu Kardynała Stefana Wyszyń- skiego, Warszawa 2006, ss. 200.
}

Marzena Dycht, adiunkt w Instytucie Pedagogiki św. Jana Bosko Uniwersytetu Kardynała Stefana Wyszyńskiego w Warszawie, wydała swą książkę nakładem uczelnianego wydawnictwa.

${ }^{*}$ Ks. dr hab. Czesław Kustra, prof. UMK, pracownik naukowy na Wydziale Nauk Pedagogicznych Uniwersytetu Mikołaja Kopernika w Toruniu. 
Autorka w przedmowie nadmienia, iż jej głównym celem było przygotowanie podręcznika, który stanowiłby kompendium podstawowej wiedzy $z$ historii pedagogiki specjalnej, ze szczególnym uwzględnieniem dokonań czołowych przedstawicieli tej nauki. Jednocześnie wyraża nadzieję, że tego typu opracowanie może stanowić okazję do uczczenia naukowego i dydaktycznego dorobku osób, tworzących podwaliny pedagogiki specjalnej oraz do przybliżenia studentom i osobom zawodowo zajmującym się problematyką szkolnictwa specjalnego wiedzy w tym zakresie.

Zasadne wydaje się jej twierdzenie, że wśród wielu znanych opracowań naukowych (czasopisma, monografie, podręczniki), odnoszących się do poszczególnych subdyscyplin pedagogiki specjalnej w Polsce, zabrakło pracy, w której rozwój pedagogiki specjalnej i dokonania jej czołowych przedstawicieli omawia się w kontekście historycznym. Dlatego też Marzena Dycht w swym opracowaniu przyjęła kryterium kompleksowości wiedzy z zakresu początków i rozwoju rodzimej pedagogiki rewalidacyjnej i resocjalizacyjnej.

Omówione zostały wszystkie działy pedagogiki specjalnej i sylwetki ich twórców: tyflopedagogika (Róża Czacka, Włodzimierz Dolański, Zofia Sękowska), oligofrenopedagogika (Kazimierz Kirejczyk), surdopedagogika (Tytus Benni), pedagogika terapeutyczna (Janina Doroszewska, Aleksander Hulek), pedagogika resocjalizacyjna (Otton Lipkowski, Stanisław Jedlewski, Czesław Czapów), pedagogika korekcyjna, pomoc logopedyczna (Wacław Ołtuszewski, Aleksandra Mitrinowicz-Modrzejewska, Halina Koneczna).

Oprócz tego, w osobnym rozdziale scharakteryzowani zostali prekursorzy polskiej pedagogiki specjalnej, do których zaliczono: Józefę Joteyko, Marię Grzegorzewską i Franciszka Jakuba Falkowskiego.

Praca opatrzona jest indeksem nazwisk i obszerną bibliografią ułożoną w porządku alfabetycznym i obejmującą łącznie 275 pozycji, wśród których przeważają prace zwarte. Obok nich odnajdziemy źródła drukowane i niedrukowane oraz materiały pokonferencyjne, a także artykuły zamieszczone na łamach czasopism i prac zbiorowych.

Przyjęty w książce alfabetyczny układ bibliografii sprzyja przejrzystości pracy, dlatego też odejście przez Autorkę od klasycznego podziału bibliograficznego, stosowanego w pracach naukowych, można uznać za uzasadnione.

Dobór materiałów wykorzystanych w książce świadczy o tym, że Autorka sprawnie porusza się $\mathrm{w}$ szeroko pojętej problematyce szkolnictwa specjalnego $i$ jest dobrze obeznana $z$ literatura przedmiotu.

Prezentacja prekursorów i twórców polskiej pedagogiki specjalnej stanowi wprowadzenie do właściwej części książki, w której prezentowane są poszczególne subdyscypliny pedagogiki specjalnej. Marzena Dycht, pisząc o Józefie Joteyko, Marii Grzegorzewskiej i Franciszku Jakubie Falkowskim, przedstawiła ich wnikliwą charakterystykę, w której znaleźć można interesujące wątki biograficzne, wspomnienia i opinie, a przede wszystkim materiał faktograficzny z zakresu szeroko pojętej działalności naukowej, dydaktycznej, wydawniczej, a także niepodległościowej tych osób. 
Przedstawienie osób związanych z tyflopedagogiką poprzedza kilkustronicowy tekst, w którym znajdziemy zarówno wyjaśnienie, jak i omówienie przedmiotu badań z zakresu rehabilitacji niewidomych oraz poznamy okoliczności powstania i rozwoju pierwszych tego typu szkół specjalnych na ziemiach polskich od XIX w. Zebrane przez Marzenę Dycht informacje na temat działalności Róży Czackiej, Włodzimierza Dolańskiego i Zofii Sękowskiej mają charakter komplementarny i umożliwiają poznanie ich dorobku naukowego oraz ewolucji tyflopedagogiki, jako nauki, w minionych latach.

Za czołowego reprezentanta oligofrenopedagogiki został uznany przez Marzenę Dycht Kazimierz Kirejczyk, którego rangę podnoszą osiagnięcia naukowe i wkład w rozwój polskiej pedagogiki terapeutycznej i surdopedagogiki. Działalność i osiagnięcia naukowe Michaliny Stefanowskiej, Jana Hellmana, Mariana Balcerka czy Marii Grzegorzewskiej zostały ledwie zasygnalizowane. Nie znajdziemy żadnych informacji o osiagnnięciach i zainteresowaniach badawczych Stefana Dziedzica czy Janiny Wyczesany. Interesujący jest rozdział poświęcony historii opieki, kształcenia i wychowania dzieci niepełnosprawnych intelektualnie na ziemiach polskich na przestrzeni dziejów. Autorka jednak mylnie podaje datę założenia pierwszej szkoły specjalnej dla dzieci upośledzonych umysłowo. Należy zgodzić się z tym, że założono ją w zaborze pruskim, w Poznaniu, ale nie w 1887, a w 1897 r. (W. Gasik, Rozwój praktyki i teorii pedagogiki specjalnej w wieku XIX i poczatkach XX w., w: S. Mauersberg, Dzieje szkolnictwa i pedagogiki specjalnej, Warszawa 1990, s. 76-104).

W rozdziale poświęconym polskiej surdopedagogice znajdujemy informacje na temat historycznego rozwoju szkół specjalnych, począwszy od nieudanych prób założenia pierwszej szkoły dla głuchych w końcowych latach I Rzeczypospolitej, poprzez ustanowienie Instytutu Głuchoniemych w Warszawie (1817 r.) i innych zakładów w okresie rozbiorów i dwudziestolecia międzywojennego, m.in. w Łodzi, Miedzyrzecu Podlaskim i we Lwowie. W dziedzinie rehabilitacji niesłyszących szczegółowo omówione zostały osiągnięcia naukowe wyłącznie Tytusa Benniego. Co prawda Autorka wspomina, że jego działalność i prace stały się następnie inspiracją dla Wacława Tułodzieckiego, Ottona Lipkowskiego, Janiny Doroszewskiej, ale wydaje się, że należało poświęcić tym uczonym nieco więcej uwagi. Postać wybitnego surdopedagoga - Eugeniusza Nurowskiego, pojawia się dwukrotnie, i to tylko w przypisach na s. 93 i 95.

W części traktującej o pedagogice terapeutycznej (leczniczej) przedstawiona została geneza i ewolucja tego działu pedagogiki specjalnej, którego rozwój w Polsce rozpoczął się właściwie po I wojnie światowej, a w szczególności po 1945 r. Oprócz tego nakreślone zostały teoretyczne podstawy pracy terapeutycznej z dziećmi przewlekle chorymi i niepełnosprawnymi ruchowo. Do grona osób mających szczególne zasługi dla rehabilitacji dzieci kalekich i chorych zaliczeni zostali Janina Doroszewska i Aleksander Hulek. Wnikliwie omówione zostały ich zainteresowania i osiagnięcia naukowe, praca zawodowa, udział w konferencjach międzynarodowych i współpraca z zagranicą. 
Za bardzo udane można by uznać wprowadzenie do polskiej pedagogiki resocjalizacyjnej. Znajdujemy tu informacje na temat form i metod oddziaływania w zakresie resocjalizacji nieletnich, od XIX wieku zwanych „moralnie zaniedbanymi". Charakterystyce poddane zostały instytucje, akty prawne, placówki i osoby tworzące podwaliny resocjalizacji (m.in. Fryderyk Skarbek, Jan Wieczorkowski). Do grona reformatorów, którzy - jak napisano - starali się wpływać na kształt myśli penitencjarnej XIX wieku, słusznie zostali zaliczeni: J. Niemcewicz, J. Pawlikowski, M. Nakwaski, W. Miklaszewski, ale zabrakło Stanisława Jachowicza. Najwięcej uwagi poświęca się twórcom pedagogiki resocjalizacyjnej w powojennej Polsce (należą do nich: Otton Lipkowski, Stanisław Jedlewski i Czesław Czapów).

Autorka stosunkowo najmniej uwagi poświęca pedagogice korekcyjnej. Motywuje to faktem, iż jest to jedna z najmłodszych dziedzin pedagogiki, której rozwój, w odróżnieniu od pozostałych działów pedagogiki specjalnej, poprzedzała nie praktyka, lecz refleksja teoretyczna. Wyjaśnione zostały podstawowe pojęcia stanowiące przedmiot pedagogiki korekcyjnej, jak: dysleksja, reedukacja, praca wyrównawcza, terapeutyczna i pedagogiczna z dziećmi ze specyficznymi trudnościami w uczeniu się. Znajdziemy tu informacje nt. wkładu poszczególnych ośrodków naukowych w rozwój tego działu nauki. Pośród wielu osób związanych z tym działem szkolnictwa wymienia się m.in.: W. Sterlinga, M. Bogdanowicz, H. Spionek, B. Marcinkowską, R. Uzdańską, H. Nartowską, B. Sawę, J. Konopnickiego, W. Petersen.

Końcowe fragmenty pracy poświecone są zagadnieniu ,pomocy logopedycznej". Jak słusznie zauważa Marzena Dycht, stanowi ona jedną z najnowszych dyscyplin pedagogiki specjalnej, której rozwój rozpoczyna się właściwie wraz z nazwiskiem i dokonaniami naukowymi Jana Siestrzyńskiego z początku XIX w. Obok niego interesująco i wyczerpująco scharakteryzowane zostały sylwetki wybitnych pedagogów, lekarzy, terapeutów i foniatrów: Wacława Ołtuszewskiego, Aleksandry Mitrinowicz-Modrzejewskiej i Haliny Konecznej oraz w węższym ujęciu - J. Szmurły, B. Dylewskiego, T. Benniego. Kontekst historyczny umożliwia zapoznanie się z ewolucją logopedii jako nauki, poznanie rozwoju i osiagnięć poszczególnych placówek terapii logopedycznej w Polsce, polityki oświatowej państwa po 1918 r., wreszcie metod oraz form kształcenia i doskonalenia zawodowego, prowadzonych w Państwowym Instytucie Pedagogiki Specjalnej w Warszawie od chwili powołania placówki w 1922 r. do czasów obecnych.

Książka Marzeny Dycht bezsprzecznie zasługuje na uwagę z kilku powodów. Po pierwsze, może ona stanowić inspirację do dalszych, poszerzonych badań w zakresie historii pedagogiki specjalnej, tak dla Autorki, jak i innych osób zajmujących się tą problematyką.

Po wtóre, liczne biogramy opatrzone bogatą faktografią, a także wielowątkowość podejmowanych tematów skłaniają do refleksji, że praca ta może być przydatna nie tylko dla studentów, ale także dla licznego grona pedagogów i historyków wychowania, którzy, jak mniemam, dobrze ocenią jej treść. 
Jestem też przekonany, że książka Marzeny Dycht, zgodnie z zamierzeniem piszącej, stanowi kompendium podstawowej wiedzy z zakresu historii pedagogiki specjalnej i w jakiejś mierze przyczynia się do przypomnienia i uczczenia naukowego dorobku przedstawionych w niej wielu osób, najbardziej zasłużonych dla polskiej pedagogiki specjalnej.

Moim zdaniem, książka mogłaby spełniać - postulowane przez Autorkę kryteria podręcznika dla studentów i osób zawodowo zajmujących się pedagogika specjalną, ale dopiero z chwila, gdy wprowadzone do niej zostaną pytania kontrolne dla studentów i propozycje metodyczne.

Jacek Kulbaka*

\section{Edward Walewander, Pedagogia katolicka w diecezji lubelskiej 1918 -1939, Towarzystwo Naukowe KUL, Lublin 2007, ss. 366 + ilustracje.}

Starożytne rozumienie pojęcia pedagogia odnosiło się do całości zabiegów związanych z formowaniem umysłowym i moralnym dziecka. Dla Greków oczywistą sprawą było, iż dzielność i sprawność fizyczną należy uzupełnić głęboką moralnością i szlachetnością duchową. Dlatego też ideałem wychowawczym była kalokagathia - połączenie piękna i dobra. Na przełomie V i IV wieku przed Chrystusem sofiści utworzyli pokrewny termin paideia. Pojęcie to określało czynności związane z kształceniem umysłowym ucznia w zakresie gramatyki, retoryki i dialektyki, a więc umiejętności niezbędnych dla wprowadzenia go w świat kultury ${ }^{1}$. Termin pedagogia oznacza zatem samo dzieło wychowywania, zespół czynności i umiejętności wychowawczych, np. pedagogia domowa, szkolna, katolicka.

Pedagogia może być twórczym oddziaływaniem na dzieci i młodzieży, które wynika z osobistego talentu wychowawcy, albo też rzemieślniczym naśladowaniem wzorów postępowania, zależnym od nabytej wprawy i rutyny. W pierwszym przypadku mamy do czynienia ze swoistą sztuka, a nawet „sztuką sztuk”, gdyż praca dotyczy trudnego materiału - człowieka. Natomiast drugi przypadek jest techniką pedagogiczna, którą można posiąść poprzez odpowiednie kursy i szkolenia dla nauczycieli, wychowawców².

Ks. prof. Edward Walewander z niezwykłą dla siebie starannością stara się czytelnikowi przybliżyć wielkie dzieło pedagogiki katolickiej w okresie międzywojennym w diecezji lubelskiej. Książka składa się z czterech rozdziałów. W pierwszym Autor przedstawia obszar i środki oddziaływania Kościoła na Lubelszczyźnie. Głównym pedagogiem jest biskup (paedagogus principalis), który pełni rolę animatora procesu wychowawczego na terenie swojej diecezji, zgodnie

* Dr Jacek Kulbaka, adiunkt w Katedrze Historii Wychowania Akademii Pedagogiki Specjalnej w Warszawie.

${ }^{1}$ Por. Leksykon PWN. Pedagogika, red. B. Milerski, B. Śliwerski, Warszawa 2000, s. 54.

${ }^{2}$ Por. S. Kunowski, Podstawy wspótczesnej pedagogiki, Warszawa 2000, s. 26. 